\title{
Sitagliptin ameliorates high glucose-induced cell proliferation and expression of the extracellular matrix in glomerular mesangial cells
}

\author{
GUAN-YING ZHANG ${ }^{1 *}$, DONG-DONG WANG ${ }^{1,2^{*}}$, ZHENG CAO $^{1 *}$, TONG WEI $^{1}$, \\ CHEN-XU LIU ${ }^{1}$ and QUN-LI WEI ${ }^{1}$ \\ ${ }^{1}$ Jiangsu Key Laboratory of New Drug Research and Clinical Pharmacy; ${ }^{2}$ Office of Academic Affairs, \\ Xuzhou Medical University, Xuzhou, Jiangsu 221004, P.R. China
}

Received September 27, 2016; Accepted May 17, 2017

DOI: $10.3892 /$ etm.2017.5002

\begin{abstract}
Diabetic nephropathy (DN) is one of the most important causes that leads to end-stage renal disease and the efficacy of strategies currently available for the prevention of DN remains unsatisfactory. Sitagliptin (SIT), which is a dipeptidyl peptidase-4 inhibitor, exhibited a modest beneficial effect on glycated hemoglobin levels and is capable of ameliorating renal ischemia reperfusion injury. By determining the expression of transforming growth factor- $\beta 1$ (TGF- $\beta 1$ ), connective tissue growth factor (CTGF), collagen type IV (ColIV) and fibronectin (FN) levels in high glucose-cultured glomerular mesangial cells (MCs), the present study aimed to assess the anti-proliferative and anti-fibrotic effects of SIT on the therapeutic potential for the prevention of DN and its mechanism. Specifically, cell proliferation was determined via cell counting kit- 8 assay, and the expression levels of TGF- $\beta 1$ and CTGF mRNA were detected by reverse transcription polymerase chain reaction analysis. Furthermore, the secretion of TGF- $\beta 1$, CTGF, ColIV and FN proteins was measured via enzyme-linked immunosorbent assays. The results demonstrated that high glucose induced the proliferation of MCs and enhanced the expression of TGF- $\beta 1$, CTGF, ColIV and FN. Furthermore, treatment with SIT inhibited cell proliferation and the expression of TGF- $\beta 1, \mathrm{CTGF}$, ColIV and FN induced by high glucose. In conclusion, SIT inhibits cell proliferation and the expression of the major extracellular matrix proteins induced by high glucose, indicating its value for treating or relieving DN.
\end{abstract}

Correspondence to: Dr Qun-Li Wei, Jiangsu Key Laboratory of New Drug Research and Clinical Pharmacy, Xuzhou Medical University, 209 Tongshan Road, Xuzhou, Jiangsu 221004, P.R. China E-mail: weiqunli@126.com

*Contributed equally

Key words: sitagliptin, diabetic nephropathy, mesangial cells, cell proliferation, extracellular matrix

\section{Introduction}

Diabetic nephropathy (DN), which is the leading cause of end-stage kidney failure, is increasing worldwide (1). Mesangial expansion of DN, caused by the proliferation of mesangial cells (MCs) and the excessive accumulation of the extracellular matrix (ECM), is one of the pathological features of DN (2). Hyperglycemia, which activates multiple intracellular signaling factors and results in abnormalities in blood flow and the accumulation of ECM (3-5), has been confirmed as the main initiative factor in the etiology of DN (6), which is one type of kidney fibrosis disease (7-9). In the clinical settings, the major ECM proteins, including collagen type IV (ColIV) and fibronectin ( $\mathrm{FN})$, are regarded as the markers of fibrogenesis in numerous kidney fibrosis diseases, such as DN. However, transforming growth factor- $\beta 1$ (TGF- $\beta 1)$ and its downstream mediator connective tissue growth factor (CTGF) are recognized as fibrogenic cytokines and have a decisive role in the kidney pathophysiology of DN $(10,11)$. At present, MCs are considered as the main type of cells that secrete ECM (12). Therefore, inhibition of MC proliferation and ECM accumulation can be applied as a practical method to treat or delay DN.

However, no therapies that are currently available are able to retard the progression of end-stage renal failure and novel treatments in the management of DN are therefore required. Sitagliptin (SIT) is one of the most well-known incretin enhancers or gliptins, which increases incretin contents due to the inhibition of dipeptidyl peptidase-4 (DPP-4) activity. Previous studies have revealed that SIT may offer cardiovascular and neuropathic protection by antioxidant, anti-inflammatory and anti-apoptotic mechanisms (13-19). It has also been reported that SIT is able to ameliorate renal ischemia reperfusion injury in rats (20). However, it is uncertain whether it has a beneficial effect on DN.

In the present study, the effects of SIT on the proliferation of MCs, the expression of major ECM (ColIV and FN) and ECM-related genes (TGF- $\beta 1$ and CTGF) were investigated in high glucose-cultured MCs. Cell proliferation was determined via a Cell Counting Kit-8 (CCK-8) assay, the mRNA levels of TGF- $\beta 1$ and CTGF genes were detected by reverse transcription polymerase chain reaction (RT-PCR) and the levels of 
TGF- $\beta 1$, CTGF, ColIV and FN proteins in the supernatant of MCs were measured by ELISA.

\section{Materials and methods}

Materials. SIT was purchased from Santa Cruz Biotechnology, Inc. (Dallas, TX, USA). Human glomerular MCs were acquired from Central South University (Changsha, China). CCK-8 was purchased from Dojindo Molecular Technologies, Inc., (Kyushu, Japan). TRIzol reagent was purchased from Thermo Fisher Scientific, Inc. (Waltham, MA, USA) and TIANScript RT kit was purchased from Tiangen Biotech Co., Ltd. (Beijing, China). Upstream and downstream primers of the TGF- $\beta 1$ and CTGF genes were purchased from Shanghai Sangon Biotech Co., Ltd. (Shanghai, China). TGF-ק1 (DRE10095), CTGF (DRE10422), ColIV (DRE10693) and FN (DRE10160) ELISA kits were purchased from RayBiotech Scientific (Southampton, UK).

MC culture and treatment. MCs were seeded at $1.0 \times 10^{6} \mathrm{cell} / \mathrm{ml}$ and cultured in Dulbecco's modified Eagle's medium (Gibco; Thermo Fisher Scientific, Inc.) at $37^{\circ} \mathrm{C}$ in a humidified atmosphere containing $5 \% \mathrm{CO}_{2}$. During the experiments, the cells were exposed to a normal concentration of glucose (NG; $5.56 \mathrm{mmol} / \mathrm{l}$ ) for $24 \mathrm{~h}$, and divided into five groups and treated with normal glucose (NG; $5.56 \mathrm{mmol} / \mathrm{l})$, high glucose (HG; $30 \mathrm{mmol} / \mathrm{l}$ glucose), high glucose with low-dose $(0.1 \mu \mathrm{mol} / \mathrm{ml})$ sitagliptin for the low dose of sitagliptin group (SITL), high glucose with medium-dose $(1 \mu \mathrm{mol} / \mathrm{ml})$ sitagliptin for the medium dose of sitagliptin group (SITM) or high glucose with high-dose $(10 \mu \mathrm{mol} / \mathrm{ml})$ sitagliptin for the high dose of sitagliptin group (SITH). SIT was dissolved in $1 \%$ (v/v) dimethyl sulfoxide (DMSO) to treat the DMSO group, which was used as a control to rule out the effect of the vehicle. In addition, mannitol (MA) was used as a control to exclude the effect of osmotic pressure. Cells were cultured at $37^{\circ} \mathrm{C}$ in a humidified atmosphere containing $5 \% \mathrm{CO}_{2}$ and harvested for analysis after 24 and $36 \mathrm{~h}$.

Cell proliferation assay. Cell proliferation was tested using the CCK-8 colorimetric method. MCs were seeded into 96-well plates at a density of $1.0 \times 10^{5} /$ well. After 24 and $36 \mathrm{~h}, \mathrm{CCK}-8$ solution was added (10 $\mu \mathrm{l}$ in each well) and cells continued to be cultured for another $1 \mathrm{~h}$. Absorbance was read at $450 \mathrm{~nm}$ by visible spectrometry (BioTek Instruments, Inc., Winooski, VT, USA).

$R T-P C R$. An RT-PCR procedure was performed to examine the relative mRNA levels of TGF- $\beta 1$ and CTGF in MCs. Total RNA was extracted from MCs using TRIzol reagent according to the manufacturer's instructions. The total RNA obtained was converted into cDNA using a TIANScript RT kit. The sequences of the primers used were as follows: TGF- $\beta 1$ forward, 5'-ATGTGCAGGATAATTGCTGCC-3' and reverse, 5'-TGGTGTTGTACAGGCTGAGG-3' (182 bp); CTGF forward, 5'-GCTAAGACCTGTGGAATGGGC-3' and reverse, 5'-CTCAAAGATGTCATTGCCCCC-3' (383 bp); and $\beta$-actin forward, 5'-ATGTCACGCACGATTTCCC-3' and reverse, 5'-GAGACCTTCAACACCCCAGC-3' (263 bp). The reaction mixture was incubated at $42^{\circ} \mathrm{C}$ for $55 \mathrm{~min}$ for $\mathrm{RT}$ prior

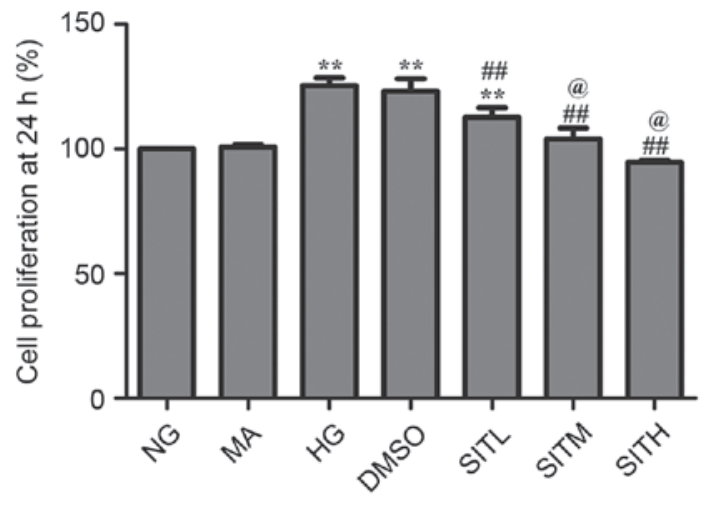

Figure 1. Cell proliferation rates in sitagliptin-treated mesangial cells at $24 \mathrm{~h}$. Data are expressed as the mean \pm standard error of the mean, $\mathrm{n}=3$. ${ }^{* *} \mathrm{P}<0.01$ vs. the NG group; ${ }^{\# \#} \mathrm{P}<0.01$ vs. the HG group; ${ }^{\circledR} \mathrm{P}<0.05$ vs. SITM. NG, normal glucose; MA, mannitol; HG, high glucose; DMSO, high glucose with $1 \%$ dimethyl sulfoxide; SITL, high glucose with $0.1 \mu \mathrm{mol} / \mathrm{ml}$ sitagliptin; SITM, high glucose with $1 \mu \mathrm{mol} / \mathrm{ml}$ sitagliptin; SITH, high glucose with $10 \mu \mathrm{mol} / \mathrm{ml}$ sitagliptin.

to thermal cycling. Cycle conditions of TGF- $\beta 1$ and CTGF genes were as follows: Initial denaturation for $3 \mathrm{~min}$ at $94^{\circ} \mathrm{C}$, followed by 30 cycles at $94^{\circ} \mathrm{C}$ for $30 \mathrm{sec}, 60^{\circ} \mathrm{C}$ for $30 \mathrm{sec}, 72^{\circ} \mathrm{C}$ for $1 \mathrm{~min}$ and a final elongation step at $72^{\circ} \mathrm{C}$ for $5 \mathrm{~min}$. For $\beta$-actin, the cycling conditions were: Initial denaturation for $3 \mathrm{~min}$ at $94^{\circ} \mathrm{C}$, followed by 35 cycles at $94^{\circ} \mathrm{C}$ for $30 \mathrm{sec}, 59^{\circ} \mathrm{C}$ for $30 \mathrm{sec}, 72^{\circ} \mathrm{C}$ for $1 \mathrm{~min}$ and a final elongation step at $72^{\circ} \mathrm{C}$ for 5 min. RT-PCR products were separated by $1.5 \%$ SDS-PAGE, and the band densities were analyzed using a Tanon-1600R gel imaging system (Tanon Science and Technology Co., Ltd., Shanghai, China). Relative quantities of mRNA of these genes in MCs that were represented by the ratio of band density of the objective gene were compared to that of $\beta$-actin.

ELISA. Levels of TGF- $\beta 1$, CTGF, ColIV and FN proteins in the supernatant of MCs were determined by ELISA according to the manufacturer's instructions. The colorimetric reaction was measured at $450 \mathrm{~nm}$.

Statistical analysis. Statistical analyses were carried out using SPSS 16.0 software (SPSS, Chicago, IL, USA). Data were expressed as the mean \pm standard error of the mean $(n=3)$. Statistical analyses were performed using one-way analysis of variance. $\mathrm{P}<0.05$ was considered to indicate a statistically significant difference.

\section{Results}

Effects of SIT on MC proliferation induced by high glucose. CCK-8 assay was used to investigate the impact of SIT on the proliferation of MCs. As demonstrated in Figs. 1 and 2, $\mathrm{MC}$ proliferation was increased after $24 \mathrm{~h}(\mathrm{P}<0.01)$ and $36 \mathrm{~h}$ $(\mathrm{P}<0.01)$ exposure to high glucose. Cell proliferation rates in the SITL, SITM and SITH groups were significantly lower than those of the HG group $(\mathrm{P}<0.05$ or $\mathrm{P}<0.01)$. However, at both time points, cell proliferation rates in the MA group were not significantly different from those in the normal glucose group (NG), and the DMSO group was almost identical to the HG group, indicating that no effects were generated by the 


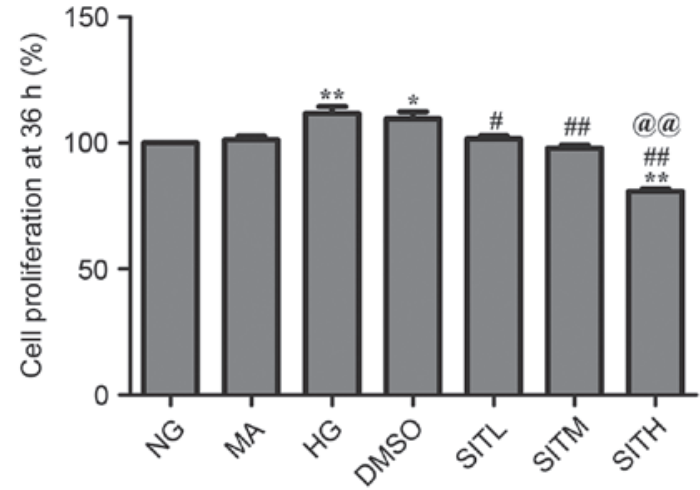

Figure 2. Cell proliferation rates in sitagliptin-treated mesangial cells at $36 \mathrm{~h}$. Data are expressed as the mean \pm standard error of the mean, $\mathrm{n}=3$. ${ }^{*} \mathrm{P}<0.05$ and ${ }^{* * *} \mathrm{P}<0.01$ vs. the NG group; ${ }^{\#} \mathrm{P}<0.05$ and ${ }^{\# *} \mathrm{P}<0.01$ vs. the HG group; ${ }^{\circledR @} \mathrm{P}<0.01$ vs. SITM. NG, normal glucose; MA, mannitol; HG, high glucose; DMSO, high glucose with $1 \%$ dimethyl sulfoxide; SITL, high glucose with $0.1 \mu \mathrm{mol} / \mathrm{ml}$ sitagliptin; SITM, high glucose with $1 \mu \mathrm{mol} / \mathrm{ml}$ sitagliptin; SITH, high glucose with $10 \mu \mathrm{mol} / \mathrm{ml}$ sitagliptin.

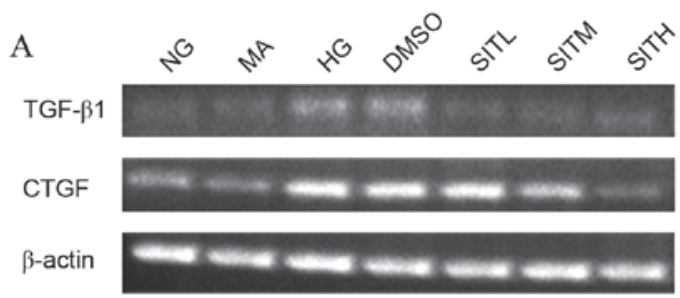

B

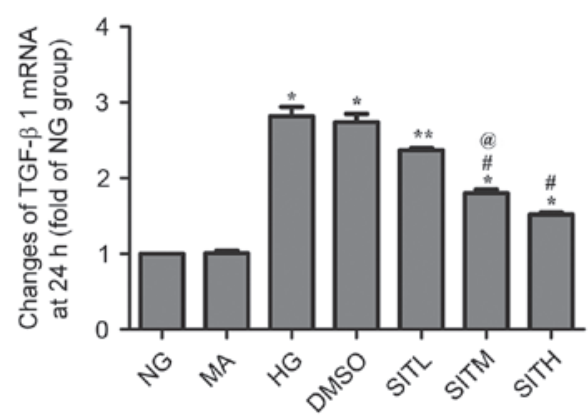

C

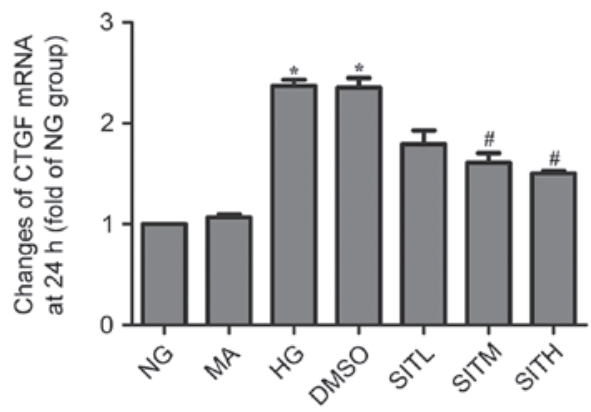

Figure 3. mRNA levels of TGF- $\beta 1$ and CTGF in the sitagliptin-treated mesangial cells at $24 \mathrm{~h}$. (A) Agarose electrophoresis of RT-PCR products amplified from the total RNA extracts of mesangial cells. $\beta$-actin was used as the internal standard in each sample. (B and C) RT-PCR data for the mRNA relative quantity of TGF- $\beta 1$ and CTGF performed by densitometric analysis. Data are expressed as the mean \pm standard error of the mean, $\mathrm{n}=3$. ${ }^{*} \mathrm{P}<0.05$ and ${ }^{* * *} \mathrm{P}<0.01$ vs. the NG group; ${ }^{\#} \mathrm{P}<0.05$ vs. the HG group; ${ }^{\circledR} \mathrm{P}<0.05$ vs. SITL. TGF- $\beta 1$, transforming growth factor- $\beta 1$; CTGF, connective tissue growth factor; NG, normal glucose; MA, mannitol; HG, high glucose; DMSO, high glucose with $1 \%$ dimethyl sulfoxide; SITL, high glucose with $0.1 \mu \mathrm{mol} / \mathrm{ml}$ sitagliptin; SITM, high glucose with $1 \mu \mathrm{mol} / \mathrm{ml}$ sitagliptin; SITH, high glucose with $10 \mu \mathrm{mol} / \mathrm{ml}$ sitagliptin; RT-PCR, reverse transcription-polymerase chain reaction.

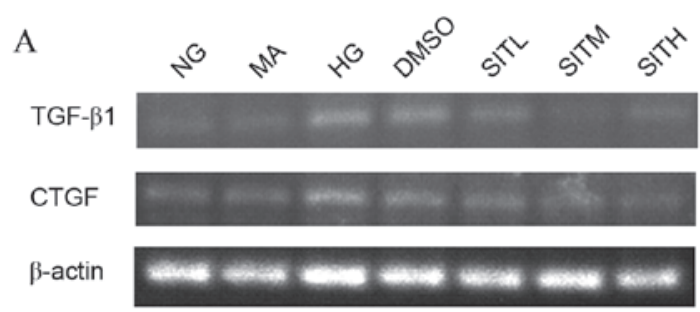

B
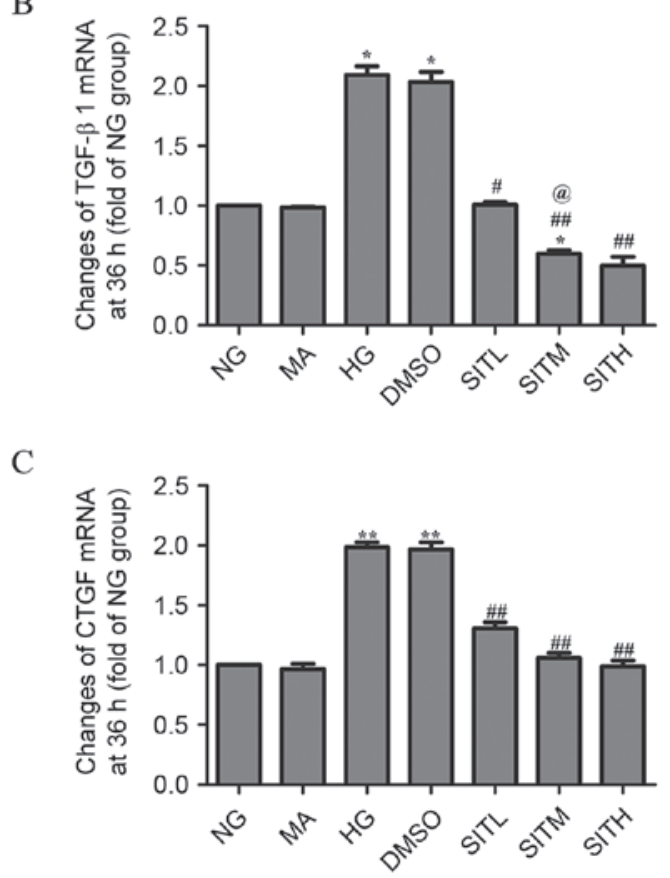

Figure 4. mRNA levels of TGF- $\beta 1$ and CTGF in the sitagliptin-treated mesangial cells at 36 h. (A) Agarose electrophoresis of RT-PCR products amplified from the total RNA extracts of mesangial cells, where $\beta$-actin was used as the internal standard in each sample. (B and C) RT-PCR data for the mRNA relative quantity of TGF- $\beta 1$ and CTGF performed by densitometric analysis. Data are expressed as the mean \pm standard error of the mean, $n=3$. ${ }^{*} \mathrm{P}<0.05$ and ${ }^{* *} \mathrm{P}<0.01$ vs. the NG group; ${ }^{\#} \mathrm{P}<0.05$ and ${ }^{\# \#} \mathrm{P}<0.01$ vs. the HG group; ${ }^{\circledR} \mathrm{P}<0.05$ vs. SITL. TGF- $\beta 1$, transforming growth factor- $\beta 1$; CTGF, connective tissue growth factor; NG, normal glucose; MA, mannitol; HG, high glucose; DMSO, high glucose with 1\% dimethyl sulfoxide; SITL, high glucose with $0.1 \mu \mathrm{mol} / \mathrm{ml}$ sitagliptin; SITM, high glucose with $1 \mu \mathrm{mol} / \mathrm{ml}$ sitagliptin; SITH, high glucose with $10 \mu \mathrm{mol} / \mathrm{ml}$ sitagliptin.

osmotic pressure and the vehicle. These results indicate that administration of SIT significantly suppressed MC proliferation induced by high glucose.

Effects of SIT on TGF- $\beta 1$ and CTGF mRNA levels induced by high glucose. As shown in Figs. 3 and 4, the results of RT-PCR analysis demonstrated that the mRNA expression levels of TGF- $\beta 1$ and CTGF in the HG-treated group were significantly upregulated compared with the NG group after $24(\mathrm{P}<0.05)$ and $36 \mathrm{~h}(\mathrm{P}<0.01)$. After $24 \mathrm{~h}$, the TGF- $\beta 1$ and CTGF mRNA levels in the groups treated with SITM and SITH were significantly lower than those of the HG group $(\mathrm{P}<0.05)$. TGF- $\beta 1$ and CTGF mRNA levels in the SITL group were not significantly lower than in the HG group. After $36 \mathrm{~h}$, the TGF- $\beta 1$ and CTGF mRNA levels in the SITL, SITM, and SITH groups were significantly decreased compared with the 

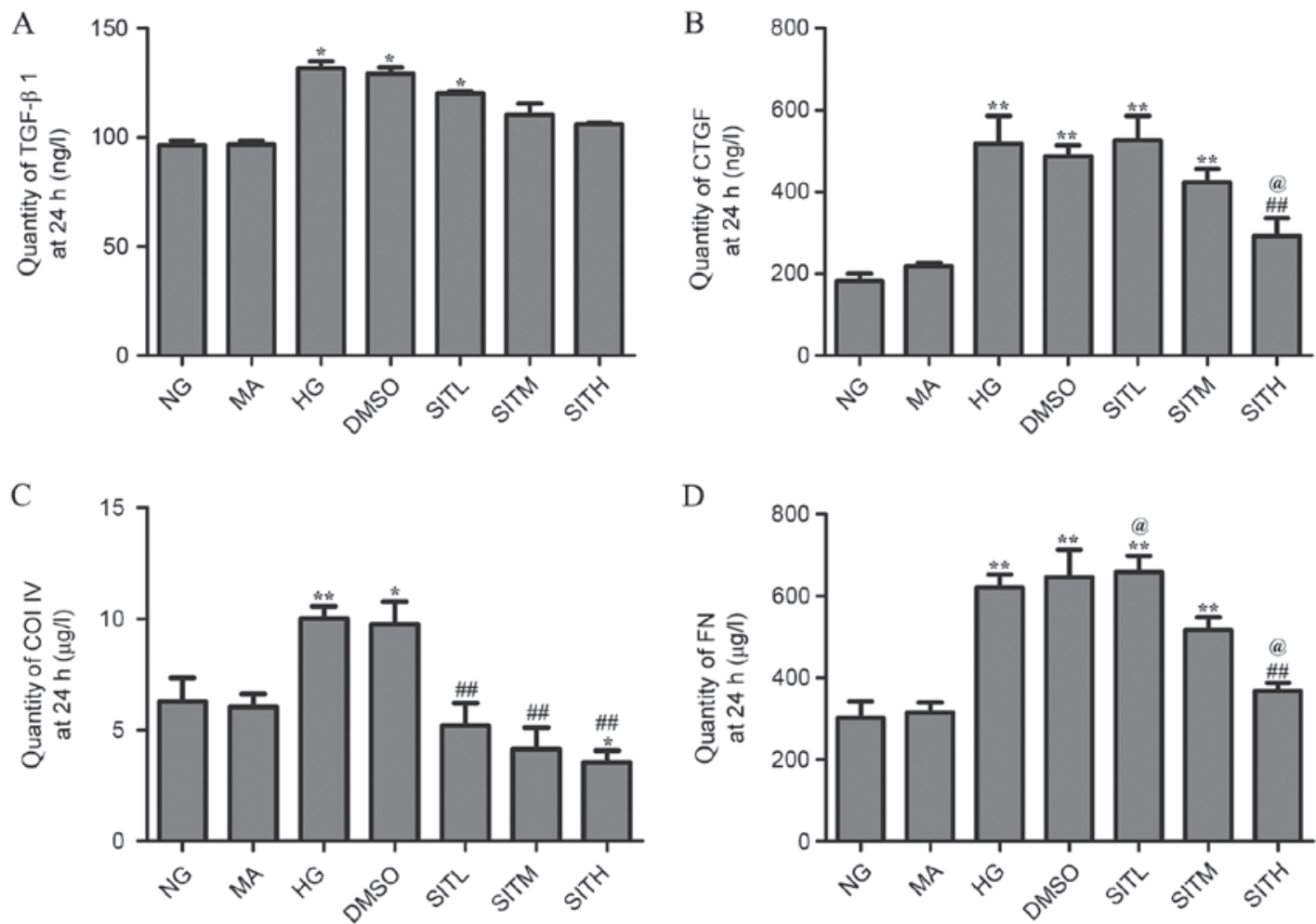

Figure 5. Quantity of TGF- $\beta 1$, CTGF, ColIV and FN proteins in the supernatant of sitagliptin-treated mesangial cells at 24 h. Quantity of (A) TGF- $\beta 1$. (B) CTGF, (C) ColIV and (D) FN. Data are expressed as the mean \pm standard error of the mean, $n=3$. ${ }^{*} \mathrm{P}<0.05$ and ${ }^{* *} \mathrm{P}<0.01$ vs. the NG group; ${ }^{\# \#} \mathrm{P}<0.01$ vs. the HG group; ${ }^{\circledR} \mathrm{P}<0.05$ vs. SITM. TGF- $\beta 1$, transforming growth factor- $\beta 1$; CTGF, connective tissue growth factor; ColIV, collagen type IV; FN, fibronectin; NG, normal glucose; MA, mannitol; HG, high glucose; DMSO, high glucose with $1 \%$ dimethyl sulfoxide; SITL, high glucose with $0.1 \mu \mathrm{mol} / \mathrm{ml}$ sitagliptin; SITM, high glucose with $1 \mu \mathrm{mol} / \mathrm{ml}$ sitagliptin; SITH, high glucose with $10 \mu \mathrm{mol} / \mathrm{ml}$ sitagliptin.
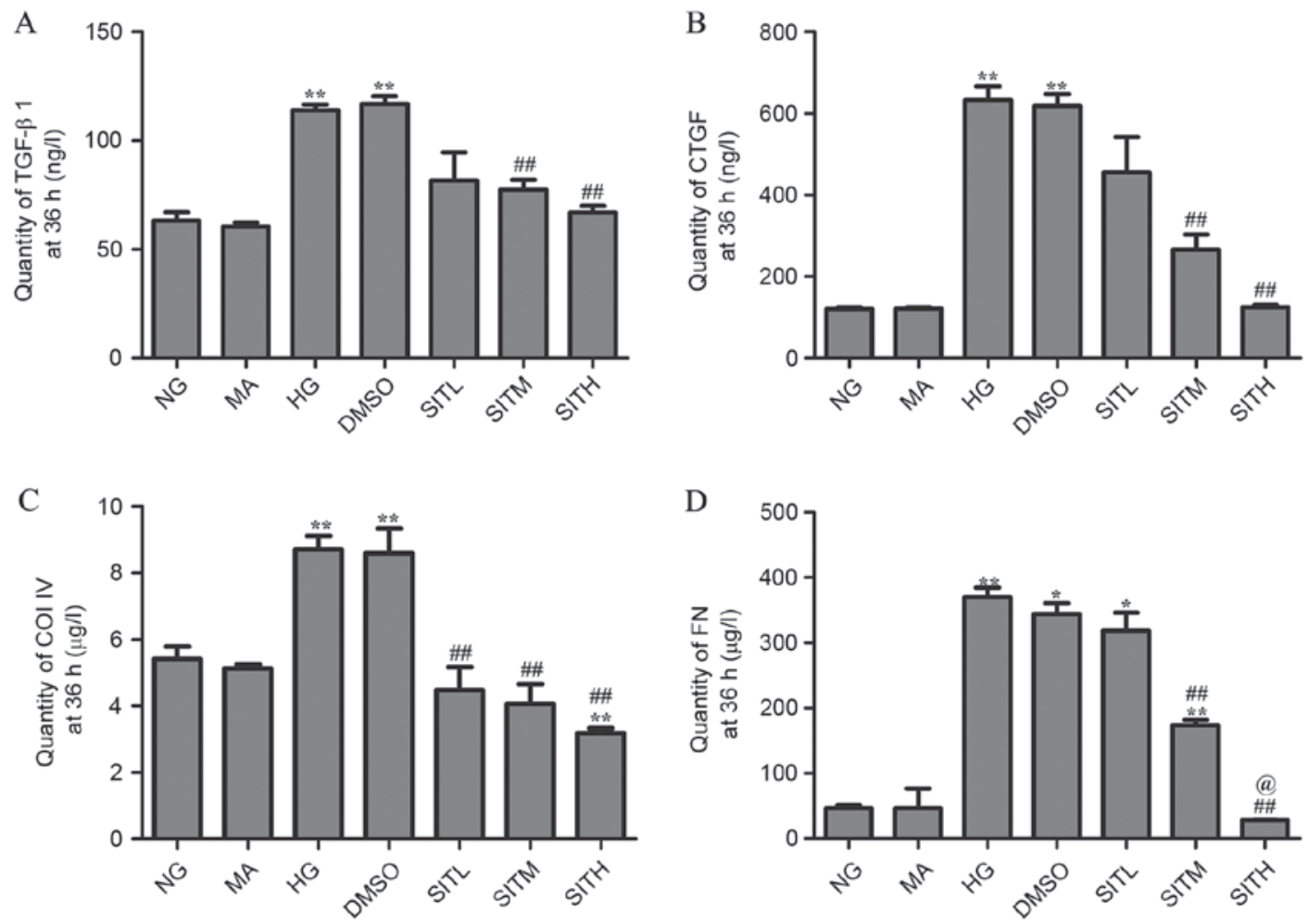

Figure 6. Quantity of TGF- $\beta 1$, CTGF, ColIV and FN proteins in the supernatant of sitagliptin-treated mesangial cells at $36 \mathrm{~h}$. Quantities of (A) TGF- $\beta 1$, (B) CTGF, (C) ColIV and (D) FN. Data are expressed as mean \pm standard error of the mean, $n=3$. "P $<0.05$ and ${ }^{* *} \mathrm{P}<0.01$ vs. the NG group; ${ }^{* \#} \mathrm{P}<0.01 \mathrm{vs}$. the HG group; ${ }^{\circledR} \mathrm{P}<0.05$ vs. SITM. TGF- $\beta 1$, transforming growth factor- $\beta 1$; CTGF, connective tissue growth factor; ColIV, collagen type IV; FN, fibronectin; NG, normal glucose; MA, mannitol; HG, high glucose; DMSO, high glucose with $1 \%$ dimethyl sulfoxide; SITL, high glucose with $0.1 \mu \mathrm{mol} / \mathrm{ml}$ sitagliptin; SITM, high glucose with $1 \mu \mathrm{mol} / \mathrm{ml}$ sitagliptin; SITH, high glucose with $10 \mu \mathrm{mol} / \mathrm{ml}$ sitagliptin. 
HG-treated group $(\mathrm{P}<0.05$ or $\mathrm{P}<0.01)$. No significant changes between the MA and NG groups were identified in terms of the gene expression levels and no effects were generated by the vehicle. These findings indicated that administration of SIT significantly decreased the mRNA levels of TGF- $\beta 1$ and CTGF under high glucose conditions and that this effect was concentration-dependent at $24 \mathrm{~h}$.

Effects of SIT on TGF- $\beta 1, C T G F$, ColIV and FN proteins induced by high glucose. At $24 \mathrm{~h}$, the levels of TGF- $\beta 1$, CTGF, ColIV and FN proteins in the cell culture supernatants of the HG group were significantly increased compared with the NG group $(\mathrm{P}<0.05$ or $\mathrm{P}<0.01$; Fig. 5). There was no difference observed between the NG and MA groups and the HG and DMSO groups in terms of the secretion of these four proteins, demonstrating that no effects were generated by the osmotic pressure and the vehicle. CTGF and FN levels in the group treated with SITH were significantly lower than those of the HG group $(\mathrm{P}<0.01)$. Additionally, the ColIV levels in groups treated with SITL, SITM and SITH were significantly decreased when compared with the HG-treated group $(\mathrm{P}<0.01)$. At $36 \mathrm{~h}$, the secretion of these four proteins in the cell culture supernatants of the HG group were significantly increased $(\mathrm{P}<0.01)$ and no effects were generated by the osmotic pressure and the vehicle (Fig. 6). Following administration of SIT, the TGF- $\beta 1$, CTGF and FN levels in the SITM and SITH groups were lower than those of the HG group $(\mathrm{P}<0.01)$. Furthermore, ColIV levels in the SITL, SITM and SITH groups were significantly decreased compared with the HG group $(\mathrm{P}<0.01)$. These results indicated that administration of SIT significantly decreased TGF- $\beta 1, \mathrm{CTGF}$, ColIV and $\mathrm{FN}$ protein levels under high glucose conditions.

\section{Discussion}

As one of the most important causes of end-stage renal disease, DN, also known as nodular diabetic glomerulosclerosis, is characterized by MC proliferation and excessive accumulation of ECM, which may ultimately lead to chronic renal failure (21). In the complex mechanisms of $\mathrm{DN}$, the hyperglycemia-TGF- $\beta 1$-ECM pathway is important. TGF- $\beta 1$ is a potent fibrogenic factor that is highly expressed in the kidneys of diabetic patients $(22,23)$. CTGF, which acts downstream of TGF- $\beta 1$, has been demonstrated to mediate the expression of ECM proteins in response to various external perturbations (23-25). In addition, CTGF facilitates TGF- $\beta 1$ signaling and consequently promotes renal fibrosis (26). It is evident that coordinated expression of TGF- $\beta 1$ and CTGF is crucial for the induction of ECM proteins and thus, for the development of DN (26). ECM accumulation in the mesangial area is typically associated with the deposition of ColIV and FN (27). Therefore, reversing changes in MC proliferation and expression of TGF- $\beta 1$, CTGF and ECM may be vital in relieving DN.

As outlined, canonical signal factors, including TGF- $\beta 1$, CTGF, FN and ColIV, regulate various physiological processes, including the development of DN. Preclinical observations and clinical studies have indicated that DPP-4 inhibitors may be a promising strategy for the treatment of ameliorating renal ischemia reperfusion injury (28). However, there is no evidence that SIT has a clear association with DN thus far.

In the present study, the proliferation of MCs and expression of TGF- $\beta 1$ and CTGF were enhanced under high glucose conditions. Consequently, these changes accelerate the accumulation of ColIV and FN proteins. The SIT treatment groups exhibited significant suppression of cell proliferation and a reduction in ColIV and FN protein levels in response to the high glucose and SIT conditions. In addition, SIT significantly decreased the mRNA and protein levels of TGF- $\beta 1$ and CTGF.

The present study is a preliminary study on the effects of SIT on DN and the results demonstrates that SIT was able to ameliorate high glucose-induced cell proliferation and expression of ECM in glomerular MCs, which may provide a basis for future research into novel treatments for patients with $\mathrm{DN}$.

\section{Acknowledgements}

The present study was funded by the National Innovative Practice Training Program for Students of Higher Education Institutions (grant no. 201410313024).

\section{References}

1. Remuzzi G, Schieppati A and Ruggenenti P: Clinical practice. Nephropathy in patients with type 2 diabetes. N Engl J Med 346: $1145-1151,2002$.

2. Wang J, Fang H, Dong B, Wang D, Li Y, Chen X, Chen L, Wei T and Wei Q: Effects of free anthraquinones extract from the rhubarb on cell proliferation and accumulation of extracellular matrix in high glucose cultured-mesangial cells. Korean J Physiol Pharmacol 19: 485-489, 2015.

3. Ha $\mathrm{H}$ and Lee HB: Reactive oxygen species as glucose signaling molecules in mesangial cells cultured under high glucose. Kidney Int Suppl 77: S19-S25, 2000.

4. Mishra R, Emancipator SN, Kern T and Simonson MS: High glucose evokes an intrinsic proapoptotic signaling pathway in mesangial cells. Kidney Int 67: 82-93, 2005.

5. Cooper ME: Interaction of metabolic and haemodynamic factors in mediating experimental diabetic nephropathy. Diabetologia 44: 1957-1972, 2001.

6. Phillips CA and Molitch ME: The relationship between glucose control and the development and progression of diabetic nephropathy. Curr Diab Rep 2: 523-529, 2002.

7. Xu W, Shao X, Tian L, Gu L, Zhang M, Wang Q, Wu B, Wang L, Yao J, Xu X, et al: Astragaloside IV ameliorates renal fibrosis via the inhibition of mitogen-activated protein kinases and antiapoptosis in vivo and in vitro. J Pharmacol Exp Ther 350: 552-562, 2014.

8. Wang JY, Yin XX, Wu YM, Tang DQ, Gao YY, Wan MR, Hou XY and Zhang B: Ginkgo biloba extract suppresses hypertrophy and extracellular matrix accumulation in rat mesangial cells. Acta Pharmacol Sin 27: 1222-1230, 2006.

9. Gonzalez J, Klein J, Chauhan SD, Neau E, Calise D, Nevoit C, Chaaya R, Miravete M, Delage C, Bascands JL, et al: Delayed treatment with plasminogen activator inhibitor-1 decoys reduces tubulointerstitial fibrosis. Exp Biol Med (Maywood) 234: 1511-1518, 2009.

10. Brosius FC III: New insights into the mechanisms of fibrosis and sclerosis in diabetic nephropathy. Rev Endocr Metab Disord 9: 245-254, 2008.

11. Gao Q, Qin WS, Jia ZH, Zheng JM, Zeng CH, Li LS and Liu ZH: Rhein improves renal lesion and ameliorates dyslipidemia in $\mathrm{db} / \mathrm{db}$ mice with diabetic nephropathy. Planta Med 76: 27-33, 2010.

12. Lal MA, Brismar H, Eklöf AC and Aperia A: Role of oxidative stress in advanced glycation end product-induced mesangial cell activation. Kidney Int 61: 2006-2014, 2002.

13. Picatoste B, Ramírez E, Caro-Vadillo A, Iborra C, Ares-Carrasco S, Egido J, Tuñón J and Lorenzo O: Sitagliptin reduces cardiac apoptosis, hypertrophy and fibrosis primarily by insulin-dependent mechanisms in experimental type-II diabetes. Potential roles of GLP-1 isoforms. PLoS One 8: e78330, 2013. 
14. Gault VA, Lennox R and Flatt PR: Sitagliptin, a dipeptidyl peptidase-4 inhibitor, improves recognition memory, oxidative stress and hippocampal neurogenesis and upregulates key genes involved in cognitive decline. Diabetes Obes Metab 17: 403-413, 2015.

15. Nade VS, Kawale LA and Patel KM: Protective effect of sitagliptin and rosuvastatin combination on vascular endothelial dysfunction in type-2 diabetes. Indian J Pharm Sci 77: 96-102, 2015.

16. Brenner C, Kränkel N, Kühlenthal S, Israel L, Remm F, Fischer C, Herbach N, Speer T, Grabmaier U, Laskowski A, et al: Short-term inhibition of DPP-4 enhances endothelial regeneration after acute arterial injury via enhanced recruitment of circulating progenitor cells. Int J Cardiol 177: 266-275, 2014

17. Tsai TH, Sun CK, Su CH, Sung PH, Chua S, Zhen YY, Leu S, Chang HW, Yang JL and Yip HK: Sitagliptin attenuated brain damage and cognitive impairment in mice with chronic cerebral hypo-perfusion through suppressing oxidative stress and inflammatory reaction. J Hypertens 33: 1001-1013, 2015.

18. El-Sahar AE, Safar MM, Zaki HF, Attia AS and Ain-Shoka AA: Sitagliptin attenuates transient cerebral ischemia/reperfusion injury in diabetic rats: Implication of the oxidative-inflammatory-apoptotic pathway. Life Sci 126: 81-86, 2015.

19. Bachor TP, Marquioni-Ramella MD and Suburo AM: Sitagliptin protects proliferation of neural progenitor cells in diabetic mice. Metab Brain Dis 30: 885-893, 2015.

20. Chang MW, Chen CH, Chen YC, Wu YC, Zhen YY, Leu S, Tsai TH, Ko SF, Sung PH, Yang CC, et al: Sitagliptin protects rat kidneys from acute ischemia-reperfusion injury via upregulation of GLP-1 and GLP-1 receptors. Acta Pharmacol Sin 36: 119-130, 2015.
21. Kanwar YS, Wada J, Sun L, Xie P, Wallner EI, Chen S, Chugh S and Danesh FR: Diabetic nephropathy: Mechanisms of renal disease progression. Exp Biol Med (Maywood) 233: 4-11, 2008.

22. Sharma K and Ziyadeh FN: Renal hypertrophy is associated with upregulation of TGF-beta 1 gene expression in diabetic BB rat and NOD mouse. Am J Physiol 267: F1094-F1001, 1994.

23. Border WA and Noble NA: Evidence that TGF-beta should be a therapeutic target in diabetic nephropathy. Kidney Int 54: 1390-1391, 1998.

24. Liu X, Luo F, Pan K, Wu W and Chen H: High glucose upregulates connective tissue growth factor expression in human vascular smooth muscle cells. BMC Cell Biol 8: 1, 2007.

25. Guha M, Xu ZG, Tung D, Lanting L and Natarajan R: Specific down-regulation of connective tissue growth factor attenuates progression of nephropathy in mouse models of type 1 and type 2 diabetes. FASEB J 21: 3355-3368, 2007.

26. Qi W, Chen X, Poronnik P and Pollock CA: Transforming growth factor-beta/connective tissue growth factor axis in the kidney. Int J Biochem Cell Biol 40: 9-13, 2008.

27. Sato S, Kawamura H, Takemoto M, Maezawa Y, Fujimoto $M$, Shimoyama T, Koshizaka M, Tsurutani Y, Watanabe A, Ueda S, et al: Halofuginone prevents extracellular matrix deposition in diabetic nephropathy. Biochem Biophys Res Commun 379: 411-416, 2009.

28. Hocher B, Reichetzeder C and Alter ML: Renal and cardiac effects of DPP-4 inhibitors-from preclinical development to clinical research. Kidney Blood Press Res 36: 65-84, 2012. 